\title{
THE EFFECT OF SOME ON-PADDOCK SHEEP WINTERING SYSTEMS ON SUBSEQUENT PASTURE PRODUCTION AND COMPOSITION
}

\author{
N. L. Round-TuRner \\ Invermay Agricultural Research Centre, Mosgiel
}

Abstract

Three systems of winter stocking of pasture were compared with winter spelling for subsequent herbage production and botanical composition on a fertile alluvial silt loam soil from 1970 to 1973. Although initial production deficits occurred in spring, increasing intensity and duration of winter stocking in 2 out of 3 experimental years did not depress subsequent total pasture production. In 2 years out of 3, high winter stocking rates resulted in significant increases in subsequent pasture production but in the third year the heaviest rate of winter stocking gave lower yields than an intermediate rate after an exceptionally wet winter. No major longterm changes in botanical composition were recorded.

\section{INTRODUCTION}

ANIMALS affect pastures through a combination of three processes : defoliation, treading and excretion. Each of these has been examined individually and, to a lesser extent, in combinatioa by researchers in New Zealand and overseas.

Pastures are likely to be particularly sensitive to these influences in winter and summer, which are often times when plants are under stress.

In choosing a wintering system a farmer must regard it as just one part of his year-round management and give due thought to its effect on overall productivity.

"All-grass wintering" is taken to mean any wintering system which includes pasture or hay as a source of feed and excludes the use of wintering pads or fodder crops. There are three broad approaches to all-grass wintering of sheep in the Otago/Southland region of New Zealand. These are:

(I) The "sacrifice paddock" approach whereby an area is set aside on which to feed out hay to large concentrations of stock. A run-out pasture or one scheduled for cultivation the following year would usually be chosen on the assumption 
that treading damage by wintering stock would seriously reduce its subsequent value as a productive pasture.

(2) The "set-stocking" approach, when pastures are stocked at or slightly below their average carrying capacity. Pasture growth would tend to provide a sub-maintenance diet and some hay might be fed from time to time.

(3) The "slow rotation" approach in which several paddocks are grazed by large mobs two or three times during the winter.

The long-term effects of (1) and (2). are likely to be greater than (3), particularly in terms of treading damage, because of th e longer duration of stocking. Defoliation is probably the major influence in method (3) and this has been thoroughly studied by other workers (e.g., Brougham, 1960; Lockhart et al., 1969).

The most comprehensive and widely known studies of treading in New Zealand are those carried out by D. B. Edmond, summarized by Brown and Evans (1973). These, and most other studies (e.g., Brown, 1968a, b, 1971) have been concerned primarily with the immediate effects of treading, or treading in summer rather thian winter, and l-rave deliberately eliminated the effects of grazing or excretion. Brougham (1960) in New Zealand and Lockhart et al. (1969) in Scotland have examined the effects of hard grazing. Other workers (e.g., Bryant et al., 1972) have studied the effects of treading by cattle.

The extent of pasture damage from treading is variable and depends, infer alia, on soil type, soil moisture, herbage cover and species composition. The necessity for pasture renovation by cultivation or regrassing to restore productivity on a winter sacrifice paddock has not been clearly established.

An experiment was conducted at Invermay Agricultural Research Station for 3 years from 1970 to 1973. Its object was to examine the overall effects of winter stocking by either the setstocking or sacrifice paddock methods on a good quality, productive pasture on fertile soil. No attempt was made to separate the effects of defoliation, treading and excretion, and the winter stacking was treated as part of the year-round management.

\section{EXPERIMENTAL}

The experiment was laid down on a 6-year-old perennial ryegrass (Lolium perenne) / white clover (Trifolium repens) dominant pasture $\mathrm{cm}$ flat land on a Wingatui alluvial silt loam soil in 
june 1970. The pasture also contained small amounts of cocksfoot (Dactylis glomerata), timothy (Phleum pratense) and weed grasses such as Yorkshore fog (Holcus lanatus), browntop (Agrostis tenuis), goosegrass (Bromus mollis) and Poa species. Annual rainfall1 for the district averaged over the 10 years immediately before the trial was $657 \mathrm{~mm}$.

A randomized block design was used, with 4 treatments and 4 replicates. The layout consisted of 2 rows of 8 paddocks separated by an access lane. Bach paddock was 0.05 ha in area $(1 / 8$ acre) rand measured 30.2 X $16.8 \mathrm{~m}$.

Winter stocking treatments were applied as follows:

(1) No stock — winter spelled (control)

(2) 20 e.e./ha for 12 weeks (June-August)

(3) 198 e.e./ha for 6 weeks (June-mid July)

(4) 198 e.e./ha for 12 weeks (June-August)

Treatment 2 was envisaged as a se.t-stocked, all-grass wintering system at a stocking rate a little below the carrying capacity of the pasture. Treatment 3 was a sacrifice paddock system holding a high concentration of sheep for the first half of the winter period only and feeding out hay. The paddocks were then closed up again to recover before spring. Treatment 4 was a winter-long sacrifice paddock at high stocking density.

The trial was stocked early in June each year, with Romney wathers in Years 1 and 3 and ewes in Year 2. In Treatments 2, 3 and 4, hay was fed out at both ends of each paddock, with the object of encouraging animals to move up and down the paddock but without spreading unconsumed hay all over the area.

In Years 1 and 2 soil volume/weight measurements were made before and after winter treatment to see if any soil compaction had taken place.

After stock were removed at the end of August, two pasture frames, each covering an area of $4.04 \mathrm{~m}^{2}$, were placed in every paddock and a uniformity cut made when pasture in the barest paddocks (Treatment 4) had reached mower height $(2$ to $3 \mathrm{~cm}$ ) . From September to the following May all paddocks were grazed by mob stocking at approximately moathly intervals with stocking rates of 190 to 390 e.e./ha for short periods (3 to 7 days). The aim was to graze all paddocks to a uniform and equal height, so stock density and grazing duration were adjusted according to the amount of herbage in each paddock. 
Pasture production was measured by a modified rate of growth . technique in which the period of growth and measurement colt-responded to the interval between grazings. After each grazing, herbage in the frames was cut with a reel mower when the pasture outside had recovered to mower height ( 2 to 3 days after stock were removed). Another area was trimmed and rhe frame placed on it. Pasture dry matter production and species composition were determined for each cut.

\section{RESULTS}

\section{Winter Stocking Period}

Table 1 summarizes climatological data and soil moisture status on a monthly basis throughout the three years of the trial.

TABLE 1: CLIMATOLOGICAL AND SOIL MOISTURE DATA

\begin{tabular}{|c|c|c|c|c|c|c|c|c|c|c|c|c|}
\hline & $\begin{array}{c}\text { Tem } \\
\text { Year } \\
1\end{array}$ & $\begin{array}{l}\text { Mean } \\
\text { peratu } \\
\text { Year } \\
2\end{array}$ & $\begin{array}{c}\text { Daily } \\
\text { ure ( } \\
\text { re } \\
3\end{array}$ & $\underset{\mathrm{C}}{\mathrm{C}} \mathrm{N}$ & $\begin{array}{c}\text { Year } \\
1\end{array}$ & $\begin{array}{l}\text { tal } \\
\text { infall } \\
\text { Year } \\
2\end{array}$ & $\begin{array}{c}\text { onthly } \\
\text { (mm) } \\
\text { Year } \\
3\end{array}$ & $\mathbf{N}$ & $\underset{1}{\mathbf{M}}$ & $\begin{array}{c}\text { Mean } \\
\text { oistur } \\
\text { Year } \\
2\end{array}$ & $\begin{array}{l}\text { Soil } \\
\text { e }(\%) \\
\text { Year } \\
3\end{array}$ & 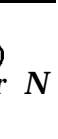 \\
\hline Jun. & 7.1 & 6.7 & 5.2 & 5.7 & 35 & 114 & 103 & 61 & 55.5 & 57.3 & 55.9 & 50.0 \\
\hline Jul. & 6.3 & 5.0 & 4.9 & 4.8 & 44 & 24 & 48 & 53 & 59.2 & 7.7 & 3.5 & 49.6 \\
\hline Aug. & 7.7 & 6.8 & 6.0 & 6.3 & 29 & 79 & 58 & 41 & 58.9 & 59.8 & 55.9 & 49.7 \\
\hline Sep. & 8.8 & 9.2 & 10.5 & 8.3 & 53 & 82 & 108 & 43 & 62.1 & 58.2 & 52.9 & 48.7 \\
\hline Oct. & 11.1 & 11.0 & 11.1 & 10.3 & 39 & 19 & 39 & 51 & 52.0 & 49.1 & 46.4 & 43.0 \\
\hline Nov. & 12.9 & 12.2 & 13.4 & 12.2 & 36 & 148 & 37 & 64 & 37.9 & 43.4 & 35.3 & 37.0 \\
\hline Dec. & 14.4 & 15.0 & 12.9 & 13.5 & 126 & 51 & 44 & 61 & 38.6 & 33.4 & 35.1 & 35.4 \\
\hline Jan. & 16.1 & 13.7 & 15.0 & 14.6 & 41 & 79 & 25 & 69 & 33.3 & 41.6 & 27.7 & 35.6 \\
\hline Feb. & 16.7 & 14.3 & 16.9 & 14.4 & 29 & 26 & 12 & 53 & 27.8 & 32.1 & 21.1 & 28.7 \\
\hline Mar. & 14.1 & 14.7 & 14.3 & 13.1 & 82 & 69 & 76 & 69 & 31.0 & 33.8 & 23.1 & 30.8 \\
\hline & 11.5 & 11.1 & 11.1 & 10.6 & 35 & 47 & 72 & 61 & 41.3 & 43.4 & 26.0 & 37.4 \\
\hline May & 9.6 & 8.0 & 7.9 & 7.6 & 101 & 120 & 56 & 61 & 47.6 & 51.2 & 44.9 & 46.4 \\
\hline
\end{tabular}

Note: Temperature and rainfall data are taken from the Taieri Invermay met. station. "N" is the official Met. Office "Normal" or average for the period 1931-1960 for temperature and 1941-1970 for rainfall. Soil moisture data (\% of oven dry weight) are taken from a regular sampling site near the trial. "N" is the average for 8 years (1965-1973).

The three successive winters of the experiment were progressively cooler and wetter, but the greatest departure from normal conditions for the district occurred in Year 3, when exceptionally high rainfall was experienced. The start of winter stocking in Year 3 coincided with heavy rainfall followed by snow. Unlike the other two winters, there were periods in Year 3 when surface 
water was lying in the paddocks. Pasture growth rates on the winter spelled treatment were $17.2,8.3$ and $6.3 \mathrm{~kg} \mathrm{DM} / \mathrm{ha} / \mathrm{day}$ in Years 1, 2 and 3, respectively.

Pastures in heavily stocked treatments were grazed bare during the winter, but there was very little evidence of pugging or severe treading effects in Years 1 and 2, when soil volume/weight measurements showed no significant increase of bulk density owing to compaction. In the wetter conditions of Year 3 slightly more pugging occurred but the difference was not marked.

\section{Subsequent Production Period}

The pattern of pasture growth rate in each year is shown in Fig. 1 and total yields in Table 2.

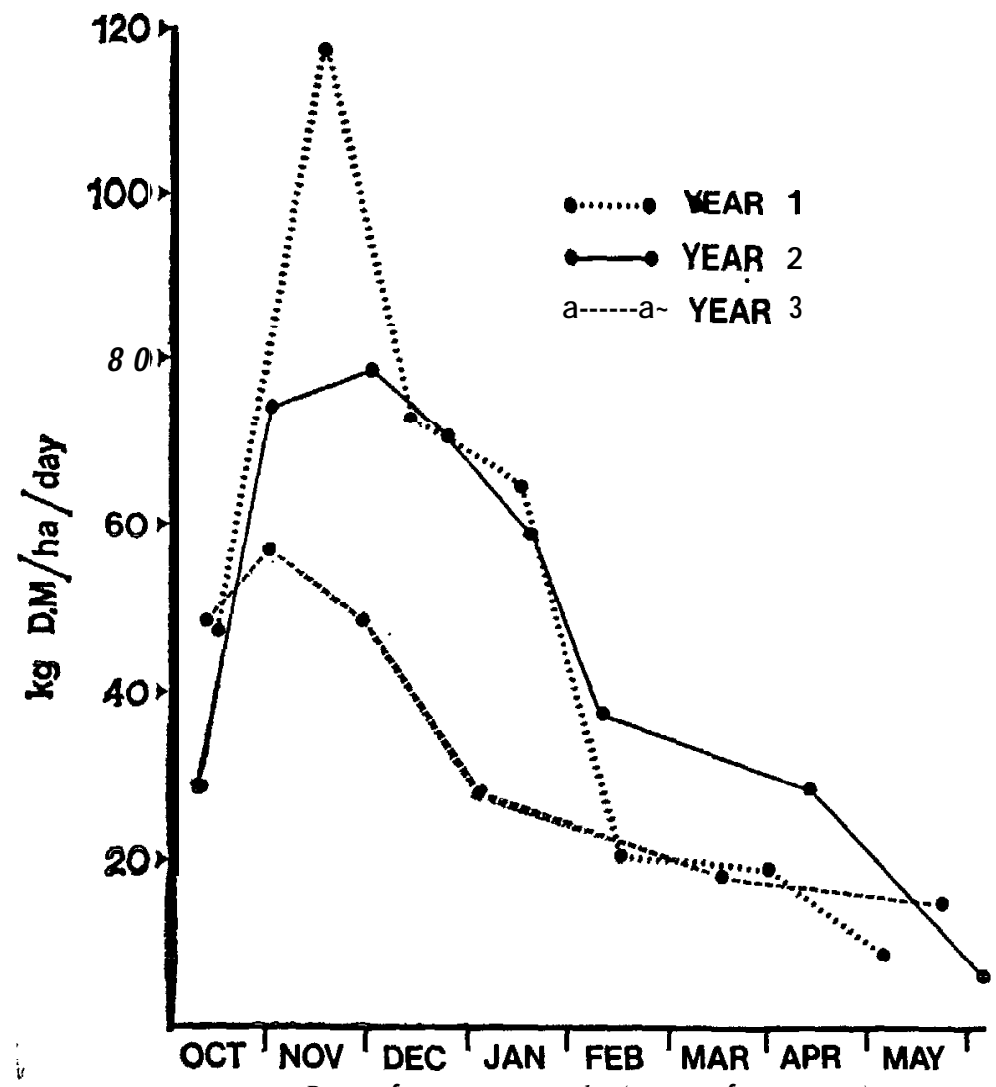

FIG. 1: Rate of pasture growth (mean of treatments). 
TABLE 2: TOTAL PASTURE PRODUCTION (kg DM/ha)

\begin{tabular}{|c|c|c|c|c|}
\hline Treatment: & 1 & 2 & 3 & 4 \\
\hline Year | (1970-1) & $9980 \mathrm{bA}$ & $10390 \mathrm{abA}$ & $10870 \mathrm{abA}$ & $11160 \mathrm{aA}$ \\
\hline Year 2 (1971-2) & $9510 \mathrm{cB}$ & $10770 \mathrm{bA}$ & $10910 \mathrm{bA}$ & $11770 \mathrm{aA}$ \\
\hline Year $3 \quad(1972-3)$ & $7020 \mathrm{abA}$ & $7140 \mathrm{abA}$ & $7580 \mathrm{aA}$ & $6310 \mathrm{bA}$ \\
\hline
\end{tabular}

Duncan's Multiple Range Test: compare across the page only. Means without a common 'letter differ significantly (lower case, $P<0.05$; capitals, $P<0.01)$.

The first two years were essentially similar in terms of total pasture production averaged over all treatments. Although there we're differences of growth rate in. the late spring period and in late summer-early autumn, these cancelled each other out. Both years had slightly above-average rainfall and soil moisture levels taken overall (Table 1).

The third year was much drier than the other two. Pasture growth rates were unusually low from November to February compared with the previous years.

\section{Treatment Total Yields}

Significant increases in total herbage production at the heaviest rate of winter stocking (Treatment 4) were recorded in the first two years. but not in Year 3. In Year 2 the intermediate treatments (2 and 3) also gave total yields significantly higher than control (Table 2). Responses were greater in Year 2 than in Year 1.

Fiģure 2 compares the rate of pasture growth during selected pericds on each treatment and in each year. The periods shown are, first, from the uniformity cut to the first production cut, secondly, the periad of highest growth rate in the season and, thirdly, the period of lowest growth, rate in the season.

Treatment 4. gave lower yields than other treatments initially but c\&yielded control during the periods of high pasture growth rate. The greater vigour of Treatment 4 pastures in Particular was clearly evident at the times of maximum growtin 'rate in November in Years 1 and 2. Responses, where they occurred, were very small in the later pert of the growing season, from January onwards.

In Years 1 and 2 all winter-stocked treameats had accumulated more dry matter production than control by the end of November, even when their growth rates had been less than 

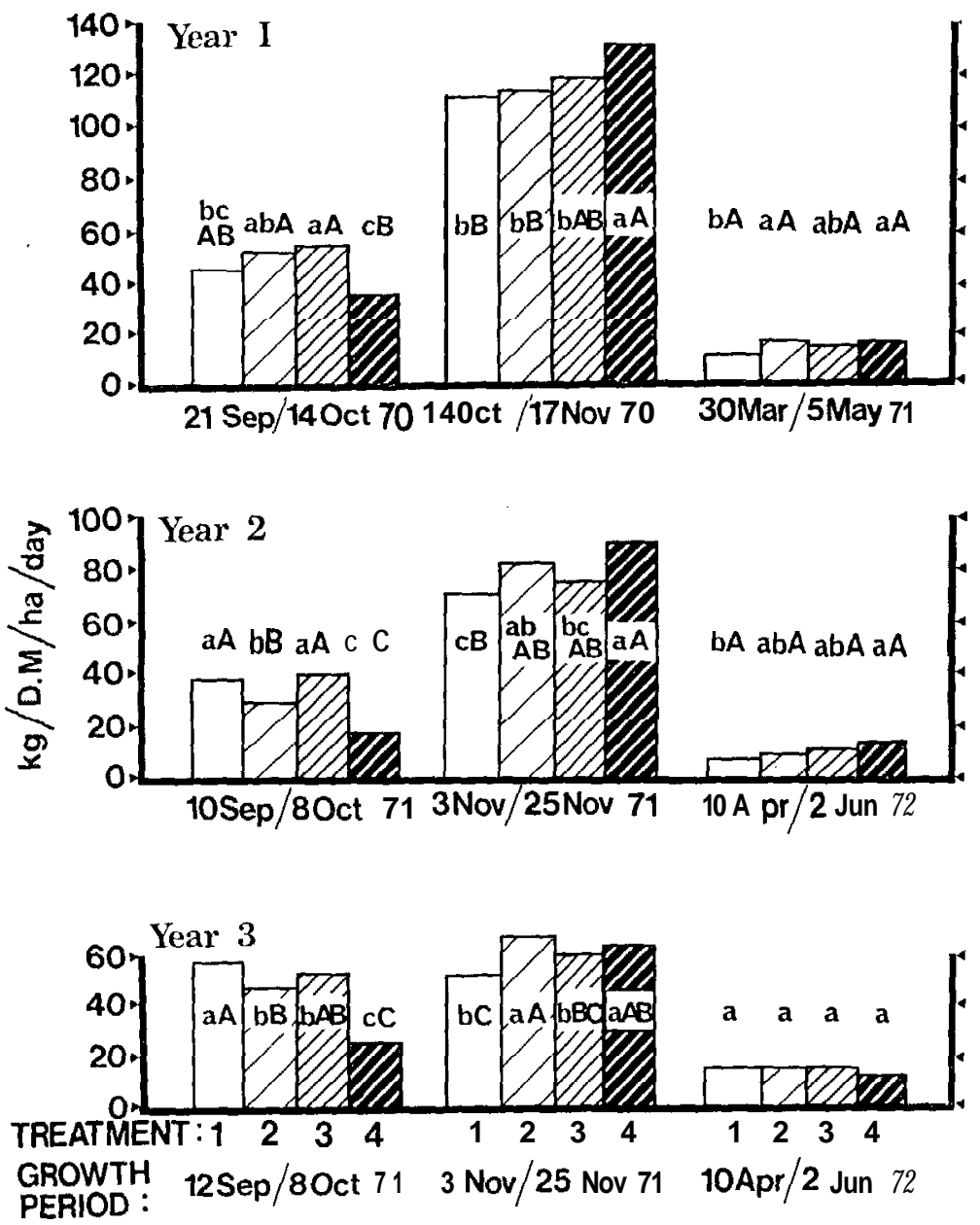

Fig. 2: Rate of pasture growth over selected periods.

control initially. In Year 3 Treatment 4 did not make up the initial deficit.

\section{Species Yields and Botanical Composition}

The botanical composition of the pasture dry matter production is shown for each treatment in each year in Fig. 3.

The most obvious features of this figure are the general similarity between treatments but marked differences between 
years in some components. The proportion of weeds increased sharply in Year 3. There was more white clover in Years 2 and 3 than Year 1. The "other grasses" component dropped after the first year and cocksfoot increased in each year. The changes
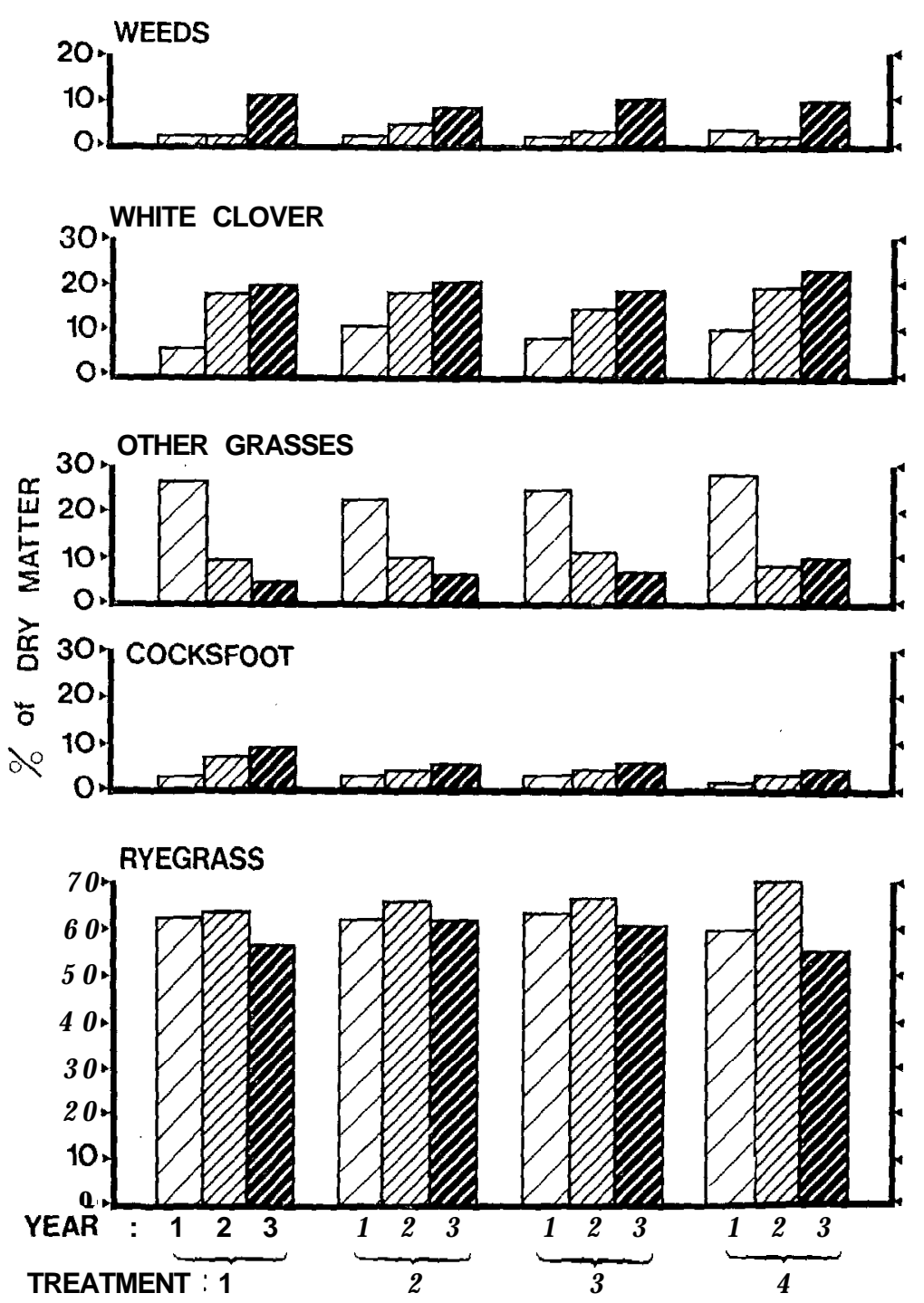

FIG. 3: Species contribution to total herbage yield. 
in ryegrass were inconsistent and small in relatioa to their total contribution, although the annual differences were more marked in Treatment 4.

There was some evidence for temporary differences in botanical composition between 'treatments at individual cuts in all years but, with the exception of cocksfoot, these were not sufficient to change rhe balance of species over the whole season. Winterstocked treatments, for example, tended to have a higher proportion of clover and less ryegrass at the first cut of the season than control. At no time during the experimental period was cocksfoot a major component of the sward, but it showed a marked tendency towards reduced production in winter-stocked treatments compared with winter-spelled pasture, and its percentage contribution to yield was reduced accordingly. This trend was most evident in Treatment 4.

\section{Herbage and Soil Chemical Analysis}

Herbage from some production cuts in Years 2 and 3 was analysed for $\mathrm{N} \%$ and $\mathrm{P} \%$. Analyses were not replicated, but there appeared to be a slight tendency fos herbage from winterstocked treatments to have a higher $\mathrm{N}$ content.

Soil analyses in May each year showed no significant differences in soil nitrogen. Significant differences in soil potassium Quick Test values in favour of Treatment 4 were found in all three years and Treatment 3 also had a significantly higher $K$ content than control in Year 3.

\section{DISCUSSION}

While the separate effects, in terms of pasture productivity and species composition, of grazing, treading and excretion by animals in winter were not distinguished, their combined effects in this trial did not result in any serious damage to pastures. In two years out of three they were of benefit to subsequent pasture production. Results confirmed findings from earlier work at Invermay (R. H. Armstrong, unpublished) that pastures on this soil type recover rapidly from winter treading.

The differences between the years, particularly the reduced responses in Year 3, seem to reflect differences in seasonal climatic conditions rather than cumulative effects of winter treatments.

The Wingatui silt loam is a deep soil in which drainage can be impeded after prolonged heavy rainfall. It tends to become "plastic" when wet so that when a compressive load is applied 
it will accommodate it by horizontal movement. The. absence of any serious degree of soil compaction or pugging reflects these characteristics.

"Clearly, treading damage is possible wherever pastures are grazed, the extent of the damage depending on stocking rate, animal management, pasture characteristics, soil fertility, etc ." (Edmoad, 1970). While the pasture characteristics in the present trial were typical of sheep pastures at Invermay, the soil was of higher fertility and less susceptible to physical damage (compaction, pugging, etc.) than most in Otago and Southland. The maximum stocking rate applied (198/ha for 12 weeks) may also have been a little lower than the rates sometimes used in practice.

The only effect in this trial which might be attributed directly to treading is the reduction of cocksfoot. Edmond (1964) found that cocksfoot was susceptible to trampling and this was confirmed by Brown (1968b) who suggested that the more elevated crowns and growing points of cocksfoot exposed it to hoof action to a greater extent than ryegrass and that low temperatures in winter restricted recovery growth. On the other hand, the reduction of cocksfoot could also be due to defoliation. Brougham (1960) found that cocksfoot yields were reduced by frequent hard grazing in winter. At Invermay, Baswell (1974) has found that severe defoliation reduce's the proportion of cocksfoot in a mixed pasture in favour 04 ryegrass and clover.

The only other apparent effect of treading was incidental to the trial and this was a reduction of grass grub numbers in Treatment 4 in April 1971. Treatment 4 paddocks had a grass grub density of $115 / \mathrm{m}^{2}$, significanitly $(\mathrm{P}<0.05)$ lower than Treatment 1 with $291 / \mathrm{m}^{2}$. Other treatments were intermediate. Previous, experience has shown that Invermay pastures on this soil type can tolerate these densities without serious damage occurring. Grass grubs had also been present before the start of the trial in May 1970. On both occasions chemical treatment was used and appeared to be effective. Heavy stocking is recommended as a method of grass grub control but normally this would not be very effective in winter. The grass grub damage could we. 11 have contributed to the low yields oh Treatment 1 in the winter of 1971 and the relative yields of Treatments 1 and 4 the following spring. It could also have delayed pasture recovery from the dry spell in February 1971.

All winter-stocked treatments recovered rapidly during the spring in each year. With the exception of Treatment 4 in Year 
3 all had accumulated more total dry matter since September by mid-November, by which time a high leaf area index had been restored.

Most previous research has shown that the effect of treading alone is to reduce subsequent pasture production. The improved production in this trial after the initial spring deficit must be explained in terms of defoliation or nutrient effects (excretion), possibly complicated by the effects of grass grub. Brougham (1960) found that frequent hard grazing in winter improved total paature yields in all subsequent seasons. Lockhart et al. (I 969) in Scotland found that grazing pastures in winter at stocking rates of 10 to 25 ewes/ha resulted in a definite reduction in the amount of herbage available in early spring. Although winter spelling resulted in spring herbage of adequate quantity, it was inferioa in quality due to the amount of senescent material present. As the grazing season progressed, differences due to winter management were reduced, so there was no effect overall.

In this situation they believed the reduction was mainly due to poaching rather than defoliation and could largely be compensated for by liberal use of nitrogen fertilizer.

The sheep on Treatments 3 and 4 were fed with a ration of hay which amounted to nearly $1 \mathrm{~kg} \mathrm{DM} / \mathrm{animal} /$ day. On a theoretical basis it was possible for Treatment 4 to have received an equivalent of $225 \mathrm{~kg}$ of nitrogen per hectare in dung and urine during the winter, and Treatment 3 half that 'amount. Herbage and soil analysis does not clearly support the hypothesis, and total soil nitrogen is a poor indicator of available $\mathrm{N}$, but it seems reasonable to conclude that the high pasture yields on winterstocked treatments can largely be attributed to this input of nutrients. The relatively high potassium status of Treatment 4 soils in autumn, nearly 9 months after the end of winter stocking, suggests that nitrogen was not the only factor, though responses to potassium have never been recorded on this soil type.

The subsequent grazing maaagement would have ensured efficient recycling of nutrients, a factor not covered by previous work at Inxermay (Armstrong, ibid.). Brockman et al. (1971) found that fertilizer nitrogen increased herbage $\mathrm{N}$ yield more on grazed than on ungrazed pasture and concluded that $\mathrm{N}$ re-circulation can be substantial on heavily stocked swards receiving high rates of fertilizer $\mathrm{N}$, particularly on soils with a high level of available soil $\mathrm{N}$. The greatest treatment responses in this trial cccurred in the spring when adequate soil moisture and 'temperatures ensured availability and utilizatioa of soil nitrogen. During 
the drier summer months, when pasture growth was checked by lower soil moisture levels, responses were no longer evident.

With the exception of cocksfoct there did not appear to be any long-term effects of treatment on the botanical composition of pastures over the year in the present trial. However, the initial spring cuts in each year tended to contain a lower proportion of ryegrass and more white clover in winter-stocked treatments than in the winter-spelled treatments. This clearly implies an effect, albeit temporary, of winter defoliation which has overcome any treadling damage to clover and reduced competition from ryegrass.

The changes in composition from year to year shown in Fig. 3 applied in all treatments. These trends must be due to seasonal effects $\mathrm{cr}$, more likely, the grazing management applied during the rest of the year after winter treatment.

\section{CONCLUSIONS}

On a fertile and resilient soil type, the advantages obtained from nutrient recycling after winter stocking, and the beneficial effects of the winter grazing itself, may outweigh any disadvantages due to treading damage as loag as winters are mild and ane followed by a moist summer and good growing conditions.

Although winter stocking has reduced the amount of feed available in spring, the combined effects of treadling, defaliatioa and animal excretion during winter in this experiment have generally resulted in greater pasture production over the remaining 9 months of the year. The possible dangers of severe treading on scme soil types when pastures are bare, especially in very wet conditions (Brown, 1968a) should not be overlooked.

When using a "sacrifice" paddock wintering system, farmers would have to ensure that adequate winter-saved pasture was available elsewhere on the farm to provide early spring feed for ewe's and lambs. Additional grazing is likely to be available again on the sacrifice paddock from mid-November onwards.

\section{ACKNOWLEDGEMENTS}

The author wishes to thank K. D. Trainor for technical assistance in the field, Miss S. M. Smith and staff of the Botanical Service's Laboratory for herbage dry matter and dissection wcrk, J. L. Grigg and staff 04 the Soil Chemistry Laboratory for soil 
and plant chemical analyses, and Dr J. Revfeim and Biometrics Section staff in Wellington for statistical analyses of the data.

\section{REFERENCES}

Boswell, C. C., 1974: In Agricultural Research in the New Zealand Ministry of Agriculture and Fisheries. Annual Report of Research Division 1973/74: 195.

Brockman, J. S.; Rope, C. M.; Stevens, M. T., 1971: J. Br. Grassld Soc., 26: 209.

Brougham, R. W., 1960: N.Z. $/ l$ agric. Res., 3: 125.

Brown, K. R., 1968a: N.Z. /l agric. Res., 11: 131.

1968b: ibid, 11:883.

-- 1971: ibid., 14: 828.

Brown, K. R.; Evans, P. S., 1973: N.Z. /l exp. Agric., 1: 217.

Bryant, H. T.; Blaser, R. E.; Peterson, J. R., 1972: Agronomy J., 64: 331.

Edmond, D. B., 1964: N.Z. Jl agric. Res., 7: 1.

1970: Proc. 11th int. Grassld Congr.: 604.

Lookhart, D. A. S.; Herriobt, J. B. D.; Cunningham, J. M. M.; Heddle, R. G., 1969:. I. Br. Grassld Soc., 24: 146. 